\title{
Antifeedant, larvicidal and growth inhibitory bioactivities of novel polyketide metabolite isolated from Streptomyces sp. AP-123 against Helicoverpa armigera and Spodoptera litura
}

\author{
Mariadhas Valan Arasu ${ }^{1,2^{*}}$, Naif Abdullah Al-Dhabi ${ }^{3}$, Valsalam Saritha ${ }^{2}$, Veeramuthu Duraipandiyan ${ }^{3}$, \\ Chinnasamy Muthukumar ${ }^{3}$ and Sun-Ju Kim ${ }^{1 *}$
}

\begin{abstract}
Background: Considerable attention has been paid to actinomycetes, especially the secondary metabolites obtained from Streptomyces species, as the best alternatives to chemicals as biological control agents for polyphagous pests such as Helicoverpa armigera and Spodoptera litura. On the basis of their novel biocontrol attributes, novel polyketide metabolite isolated from marine Streptomyces sp. AP-123 exhibited significant antifeedant, larvicidal and growth inhibitory activities against polyphagous pests.

Results: Leaf disc no-choice method was used for the insect bioassay. The polyketide metabolite presented significant antifeedant activities against H. armigera (78.51\%) and S. litura (70.75\%) at 1000 ppm concentration. The metabolite also exhibited high larvicidal activities against $\mathrm{H}$. armigera (63.11\%) and S. litura (58.22\%) and the $\mathrm{LC}_{50}$ values were $645.25 \mathrm{ppm}$ for $\mathrm{H}$. armigera and $806.54 \mathrm{ppm}$ for S. litura. The metabolite also prolonged the larval-pupal duration of the insects at all the tested concentrations.

Conclusions: The activities of the polyketide metabolite were concentration dependent for both the insects therefore it could be used as an agent to prepare new pesticidal formulations.
\end{abstract}

Keywords: Streptomyces sp. AP-123, Polyketide metabolite, Antifeedant, Larvicidal, Helicoverpa armigera, Spodoptera litura

\section{Background}

According to the report of FAO, US $\$ 120$ billion losses worldwide were caused by $20-40 \%$ decrease in crop yield, due to the attack from pathogenic organisms and insect pests [1]. Helicoverpa armigera and Spodoptera litura are the major polyphagous pests attacking more than 150 different host species and affect the vegetable yield [2]. Therefore these pests are considered as the most economically important insect pests in many countries including India, Japan, China and Southeast Asia. Controlling these polyphagous pests becomes the challenging work in agriculture field. There are few

\footnotetext{
* Correspondence: mvalanarasu@gmail.com; kimsunju@cnu.ac.kr 'Department of Bio-Environmental Chemistry, Chungnam National University, 99 Daehak-Ro, Yuseong-Gu, Daejeon 305-764, Republic of Korea

${ }^{2}$ Global Research Centre for Biotechnology, Taramani, Chennai, India Full list of author information is available at the end of the article
}

chemical insecticides and pesticides are commercially available in the market. Usage of different varieties of chemical insecticides and pesticides to control insects has resulted in emergence of pesticide resistance in the pests [3]. To ensure the stable and high output of crops, huge amount of pesticides were applied to control the pests, and this not only caused serious environmental pollution but also induced in a wide range of pesticide resistance. Meanwhile by applying these chemical pesticides different varieties of pest predators were killed and the ecological balance was destroyed, thereby causing pest resurgence and a greater outbreak of secondary pests [4]. Due to this reason, many researchers have involved on alternative control methods. Botanical and microbial pesticides are having advantage over chemical pesticides by its highly effective, safe, 
and ecologically acceptable nature. Fortunately, biopesticides have been gaining increased attention and interest among those concerned with developing environment friendly and safe integrated crop management, with compatible approaches and tactics for pest management [5].

Natural products derived from plants and microorganisms have been used for insect control [6]. Azadirachtin, a natural compound isolated from neem Azadirachta indica, is considered superior over other compounds since it has wide range of biological activities. Azadirachtin has been studied by many researchers and used as positive control. Bacterial and viral-based insecticides controlled different pests. Most of the pesticides from microorganisms have been isolated from entomo-pathogens and the terrestrial environment [7]. Recent studies on marine microorganisms have focused mainly on the discovery of human drugs, whereas limited information about marine microorganisms possessing insecticidal activities has been reported. However marine environment, representing more than two thirds of our planet, is still under-explored and is considered to be a prolific resource for the isolation of less exploited microorganisms [8]. The ocean is a resource of huge drug, where more than 6000 kinds of novel chemical compounds have been isolated from marine living organisms, among which more than 1000 compounds exert biological activities, such as anti-tumour, anti-microbial and anti-virus, etc. [9].

Recently, Streptomyces sp. AP-123 producing polyketide metabolite (Figure 1) was reported by analyzing the presence of polyketide biosynthesis (PKS) biosynthetic cluster [10]. Streptomyces sp. AP-123, a Gram positive, filamentous, spore-forming antagonistic bacteria recovered from marine region at Andhra Pradesh, India. Polyketide metabolite isolated from Streptomyces sp. AP-123 acted as a growth inhibitor of Gram-positive, Gram-negative bacteria and filamentous fungi. No reports are available on the effect of polyketide metabolite against the polyphagous pest $H$. armigera and $S$. litura. The present study was aimed at assessing the antifeedant, larvicidal, pupicidal and growth inhibitory effect of polyketide metabolite isolated from Streptomyces sp. AP-123 against $H$. armigera and S. litura .

\section{Results and discussion}

In the present study, polyketide metabolite derived from Streptomyces sp. AP-123 revealed strong antifeedant activity of $78.51 \%$ and $70.75 \%$ against $H$. armigera and $S$. litura, respectively at $1000 \mathrm{ppm}$ concentration and the activity was statistically significant over control $(\mathrm{P} \leq 0.05)$ (Table 1$)$. The bioactivity was directly proportional to the concentration of the metabolite. Polyketide metabolite showed $68.41 \%$ and $60.02 \%$ larvicidal activities against $H$. armigera and S. litura, respectively at $1000 \mathrm{ppm}$ and the activity was statistically significant compared to control $(\mathrm{P} \leq 0.05)$ (Table 2). The metabolite exhibit marked toxicity effect on the larvae of $H$. armigera and S. litura. The larvae which had consumed less amount of treated diet showed higher amount of larval mortality. The $\mathrm{LC}_{50}$ and $\mathrm{LC}_{90}$ values were 645.25 and $1724.58 \mathrm{ppm}$ and 806.54 and 1725.50 ppm for H. armigera and S. litura, respectively.

Table 3 shows pupicidal activity of polyketide metabolite consumed larvae of $H$. armigera and S. litura, respectively. After treatment with polyketide metabolite the larval and pupal developmental periods were increased significantly. The interference of toxic substances in the moulting process triggers the larval duration. Due to the treatment of the compound; larvae become small in size and various kinds of abnormalities were observed, therefore the larvae

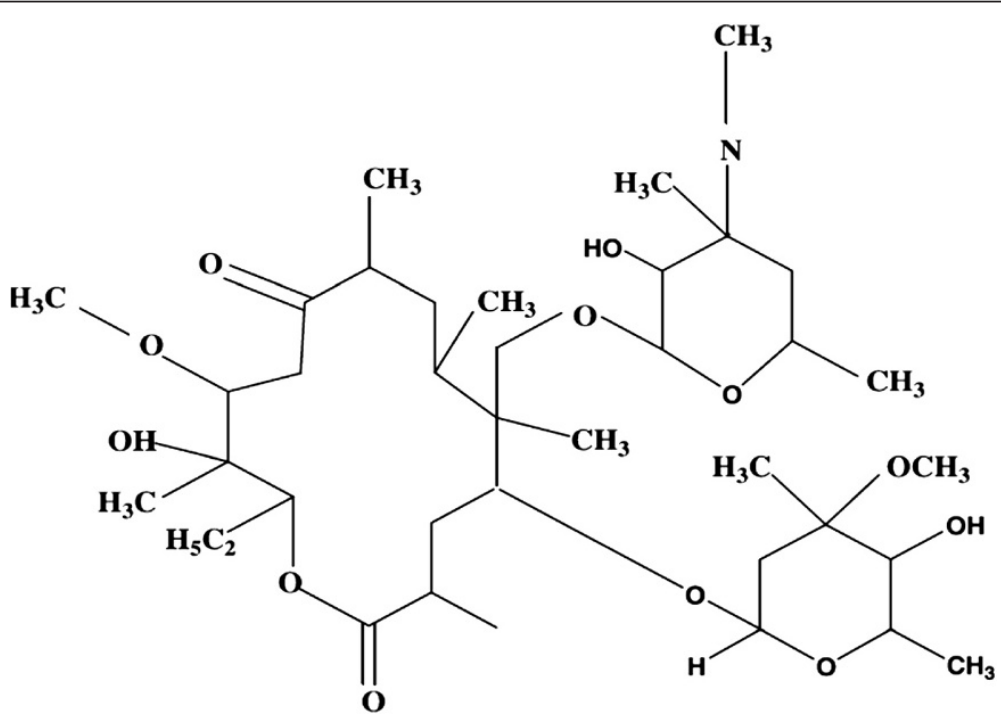

Figure 1 Polyketide antimicrobial metabolite isolated from Streptomyces sp. AP-123 [10]. 
Table 1 Antifeedant activity of polyketide metabolite against $\boldsymbol{H}$. armigera and S. litura

\begin{tabular}{lll}
\hline Concentration (ppm) & \multicolumn{2}{l}{ Antifeedant activity (\%) } \\
\cline { 2 - 3 } & H. armigera & S. litura \\
\hline Polyketide metabolite & \\
125 & $38.01 \pm 2.11^{\mathrm{b}}$ & $35.93 \pm 3.14^{\mathrm{b}}$ \\
250 & $51.77 \pm 3.81^{\mathrm{c}}$ & $46.19 \pm 3.88^{\mathrm{c}}$ \\
500 & $64.29 \pm 3.78^{\mathrm{d}}$ & $59.58 \pm 2.41^{\mathrm{d}}$ \\
1000 & $78.51 \pm 3.90^{\mathrm{e}, \mathrm{f}}$ & $70.75 \pm 2.46^{\mathrm{e}}$ f $^{-}$ \\
Azadirachtin & & \\
125 & $62.20 \pm 3.05^{\mathrm{d}}$ & $65.47 \pm 2.92^{\mathrm{e}}$ \\
250 & $64.37 \pm 3.26^{\mathrm{d}, \mathrm{e}}$ & $75.41 \pm 5.34^{\mathrm{f}}$ \\
500 & $74.51 \pm 4.95^{\mathrm{f}}$ & $83.73 \pm 3.53^{\mathrm{g}}$ \\
1000 & $89.84 \pm 5.65^{\mathrm{g}}$ & $89.61 \pm 2.88^{\mathrm{h}}$ \\
Control & $4.33 \pm 1.07^{\mathrm{a}}$ & $1.54 \pm 1.04^{\mathrm{a}}$ \\
\hline
\end{tabular}

Mean \pm SD within columns followed by the same letter do not differ significantly using Tukey's test, $\mathrm{P} \leq 0.05$.

were not able to go into further instars. The larvae were unable to continue normal physiological processes since the larvae consumed very low amount of diet. Moulting was also delayed. Larval developmental period was increased in treatment (13.98 and $13.96 \mathrm{~d}$ ) when compared to control (9.08 and $8.95 \mathrm{~d}$ ) for $H$. armigera and S. litura, respectively. Pupal duration was also increased in treatment (15.45 and $14.4 \mathrm{~d}$ ) when compared to control (9.58 and $11.12 \mathrm{~d}$ ) for $H$. armigera and S. litura, respectively. The metabolite showed pupicidal activities of $62.01 \%$ and $55.06 \%$ against $H$. armigera and S. litura, respectively at $1000 \mathrm{ppm}$ concentration (Table 3 ). Pupicidal activities were statistically significant with increasing concentrations of the compound. In general, prolonged larval-pupal durations were directly proportional to the increase in pupicidal activities.
Treatment produced different kinds of abnormalities such as larval-pupal, pupal-adult intermediate and adult abnormalities were also observed.

In the present study, polyketide metabolite exhibited maximum antifeedant activity of $78.51 \%$ and $70.75 \%$ at $1000 \mathrm{ppm}$ concentration against $H$. armigera and S. litura. This result coincided with earlier results of Kannan who had isolated violacein from Chromobacterium violaceum claimed more than $80 \%$ antifeedancy at $1000 \mathrm{ppm}$ against H.armigera [11]. Xiang et al. isolated novel macrocyclic lactone from Streptomyces microflavus neau3, showed high acaricidal activity against adult mites and nematocidal activity against Caenorhabditis elegans [12].

In the present study, significant larvicidal activity was observed at $1000 \mathrm{ppm}$ concentration against $H$. armigera and $S$. litura, respectively. Becher et al. reported that 12-epi-Hapalindole J isonitrile isolated from soil bacterium showed 100\% larvicidal activity against Chironomus riparius [13]. Three different strains of B. thuringiensis showed larvicidal activity ranging between $62 \%$ and $96 \%$ against Spodoptera frugiperda and 100\% against Anticarsia gemmatalis [14]. In this study some adults emerged and were small in size with varied abnormalities. $20 \%$ of the world's top-selling pharmaceuticals and their and derived compounds were polyketide in nature and thus represent one of the most important classes of natural products, with combined revenues of over $\$ 18$ billion per year [15]. Microbial polyketides are synthesized by serialized reactions of a set of enzymes called PKS with extraordinary structural diversity and an irregular distribution between strains and species, and they have been considered to play vital roles antimicrobial agents for pathogenic bacteria, fungi and also used as in pest control agents to kill insects and pests [16]. Spinosyns recovered from microorganism showed potent insecticidal activities against many commercially significant species that cause extensive damage

Table 2 Larvicidal(\%) and effective concentrations ( $L C_{50}$ and $L C_{90} \mathrm{ppm}$ ) of polyketide metabolite against $H$. armigera and S. litura

\begin{tabular}{|c|c|c|c|c|c|c|}
\hline \multirow{2}{*}{$\begin{array}{l}\text { Concentration } \\
\text { (ppm) }\end{array}$} & \multicolumn{3}{|c|}{ H. armigera } & \multicolumn{3}{|c|}{ S. litura } \\
\hline & Larvicidal (\%) & $\mathrm{LC}_{50}$ & $\mathrm{LC}_{90}$ & Larvicidal (\%) & $\mathrm{LC}_{50}$ & $\mathrm{LC}_{90}$ \\
\hline \multicolumn{7}{|c|}{ Polyketide metabolite } \\
\hline 125 & $15.52 \pm 5.29^{\mathrm{a}}$ & & & $10.44 \pm 0.60^{\mathrm{a}}$ & & \\
\hline 250 & $33.16 \pm 4.34^{b}$ & 645.25 & 1724.58 & $29.11 \pm 4.11^{b}$ & 806.54 & 1725.01 \\
\hline 500 & $54.08 \pm 5.63^{c}$ & & & $47.77 \pm 3.04^{c}$ & & \\
\hline 1000 & $68.41 \pm 6.04^{d}$ & & & $60.02 \pm 2.43^{d}$ & & \\
\hline \multicolumn{7}{|l|}{ Azadirachtin } \\
\hline 125 & $47.77 \pm 4.26^{c}$ & & & $51.98 \pm 5.95^{\mathrm{c}, \mathrm{d}}$ & & \\
\hline 250 & $63.66 \pm 4.47^{d}$ & 170.48 & 401.65 & $69.18 \pm 6.42^{\mathrm{e}}$ & 135.58 & 452.02 \\
\hline 500 & $98.77 \pm 4.45^{e}$ & & & $95.77 \pm 5.18^{f}$ & & \\
\hline 1000 & $100 \pm 00^{e}$ & & & $100 \pm 00^{f}$ & & \\
\hline
\end{tabular}


Table 3 Growth inhibitory activity of polyketide metabolite against $H$. armigera and S. litura

\begin{tabular}{|c|c|c|c|c|c|c|c|c|c|c|}
\hline \multirow{2}{*}{$\begin{array}{l}\text { Concentration } \\
\text { (ppm) }\end{array}$} & \multicolumn{5}{|c|}{ H. armigera } & \multicolumn{5}{|c|}{ S. litura } \\
\hline & $\mathrm{N}^{*}$ & $\begin{array}{l}\text { Larval } \\
\text { duration (d) }\end{array}$ & Pupicidal (\%) & $\mathrm{N}^{*}$ & $\begin{array}{l}\text { Pupal } \\
\text { duration (d) }\end{array}$ & $\mathrm{N}^{*}$ & $\begin{array}{l}\text { Larval } \\
\text { duration (d) }\end{array}$ & Pupicidal (\%) & $\mathrm{N}^{*}$ & $\begin{array}{l}\text { Pupal } \\
\text { duration (d) }\end{array}$ \\
\hline \multicolumn{11}{|c|}{ Polyketide metabolite } \\
\hline 125 & 42 & $10.09 \pm 0.44^{b}$ & $20.99 \pm 4.15^{b}$ & 33 & $11.45 \pm 0.40^{\mathrm{b}}$ & 43 & $10.02 \pm 0.29^{a, b}$ & $18.51 \pm 6.33^{b}$ & 35 & $10.28 \pm 0.22 a$ \\
\hline 250 & 33 & $10.91 \pm 0.35^{b, c}$ & $32.58 \pm 5.20^{\mathrm{b}, \mathrm{c}}$ & 24 & $12.35 \pm 0.46^{\mathrm{b}, \mathrm{c}}$ & 34 & $10.44 \pm 0.87^{b}$ & $25.06 \pm 7.22^{b}$ & 25 & $11.53 \pm 0.69 b$ \\
\hline 500 & 24 & $12.55 \pm 0.37^{c}$ & $42.55 \pm 3.47^{c}$ & 14 & $13.50 \pm 0.70^{c}$ & 21 & $11.96 \pm 0.45^{c}$ & $47.13 \pm 10.9^{c}$ & 11 & $13.86 \pm 0.63 c$ \\
\hline 1000 & 18 & $13.98 \pm 0.51^{d}$ & $62.01 \pm 11.7^{d}$ & 8 & $15.45 \pm 1.03^{d}$ & 18 & $13.96 \pm 0.92^{c}$ & $55.06 \pm 9.12^{c}$ & 8 & $14.4 \pm 0.54 \mathrm{~cd}$ \\
\hline \multicolumn{11}{|l|}{ Azadirachtin } \\
\hline 125 & 26 & $14.09 \pm 0.16^{e}$ & $70.45 \pm 9.04^{d}$ & 8 & $17.95 \pm 0.54^{\mathrm{e}}$ & 23 & $14.56 \pm 0.26^{\mathrm{d}, \mathrm{e}}$ & $47.40 \pm 7.48^{c}$ & 12 & $14.10 \pm 0.48 c$ \\
\hline 250 & 17 & $15.8 \pm 0.74^{f}$ & $100 \pm 00^{e}$ & & & 15 & $15.95 \pm 0.98^{e}$ & $76.08 \pm 12.9^{d}$ & 4 & $15.24 \pm 0.5 d$ \\
\hline 500 & 0 & & & & & & & & & \\
\hline \multicolumn{11}{|l|}{1000} \\
\hline Control & 48 & $9.08 \pm 0.15^{a}$ & $0^{\mathrm{a}}$ & 48 & $9.58^{\mathrm{a}}$ & 48 & & $8.95 \pm 0.49^{\mathrm{a}}$ & 48 & $11.12 \pm 0.39 a$ \\
\hline
\end{tabular}

Mean \pm SD within columns followed by the same letter do not differ significantly using Tukey's test, $P \leq 0.05 . N^{*}:$ number.

to crops and other plants. They also exhibit activity against important external parasites of livestock, companion animals and humans [17]. Several microbial polyketides, such as avermectins and milbemycins, have been reported as potent insecticides against various insects and parasites. Furthermore, they are believed to be the biggest selling and arguably most effective acaricides and anthelmintics currently available [18]. Of the 7000 known polyketide structures, more than $0.3 \%$ has been commercialized [19]. Given the importance and potential of these compounds, the discovery of microbial polyketides has drawn increasing attention.

\section{Conclusions}

In conclusion, polyketide metabolite showed good antifeedant, larvicidal, pupicidal and growth inhibitory activities against $H$. armigera and $S$. litura. The results indicated that polyketide metabolite would be a potential insecticide. This study is the first report on antifeedant, larvicidal, pupicidal and growth inhibitory activities against $H$. armigera and $S$. litura. This metabolite could be used for the development of new insecticidal formulation for the management of field pests.

\section{Methods}

Isolation and identification of Streptomyces sp. AP-123

Streptomyces sp. AP-123 was isolated from Andra Pradesh coast of the Bay of Bengal, India. The 16S rDNA gene (accession number JQ283107) based phylogenetic affiliation was determined by using bioinformatics tools identified Streptomyces sp. AP-123 as Streptomyces sp. with 99\% sequence similarity to Streptomyces flavogrecius (Figure 2).
Isolation and identification of polyketide metabolite Isolation of polyketide metabolite and its identification have already been described in our earlier manuscript [10].

\section{Insect culture collection and monitoring}

Larvae of S. litura and $H$. armigera were collected from the farmers' field in Kancheepuram district, Tamil Nadu. Insects were cultured by following the methods of Basker et al. [20]. Briefely, the collected $H$. armigera larvae were reared individually in a plastic container (vials) and fed regularly with lady's finger, Abelmoschus esculentus L. (Malvaceae) and S. litura larvae were reared on castor leaves and were kept till the larvae became pupae under the laboratory conditions $\left(27 \pm 2^{\circ} \mathrm{C}\right.$ and $74 \pm 5 \%$ relative humidity). The sterile soil was provided for pupation. After pupation, the pupae were collected from the soil and placed in inside the cage for emergence of adults. Cotton soaked with $10 \%$ honey solution (Dabur Honey, India) mixed with a few drops of multi-vitamins (Hi-Media, Mumbai) was provided for adult feeding to increase the fecundity. Potted cowpea plants were kept for $H$. armigera and groundnut plants were provided for $S$. litura separately inside the adult emergence cages for egg laying. After hatching, the larvae were collected from the cage and fed with standard artificial diet as recommended by Koul et al. [21] for $H$. armigera. Castor leaf was provided for S. litura.

\section{Antifeedant activity of the polyketide metabolite}

Antifeedant activity of polyketide metabolite was evaluated using leaf disc no-choice method described by Basker et al. [20]. Briefly, fresh young cotton (H. arigera) and castor ( $S$. litura) leaves were collected and cleaned thoroughly with water to remove the dust and other particles 


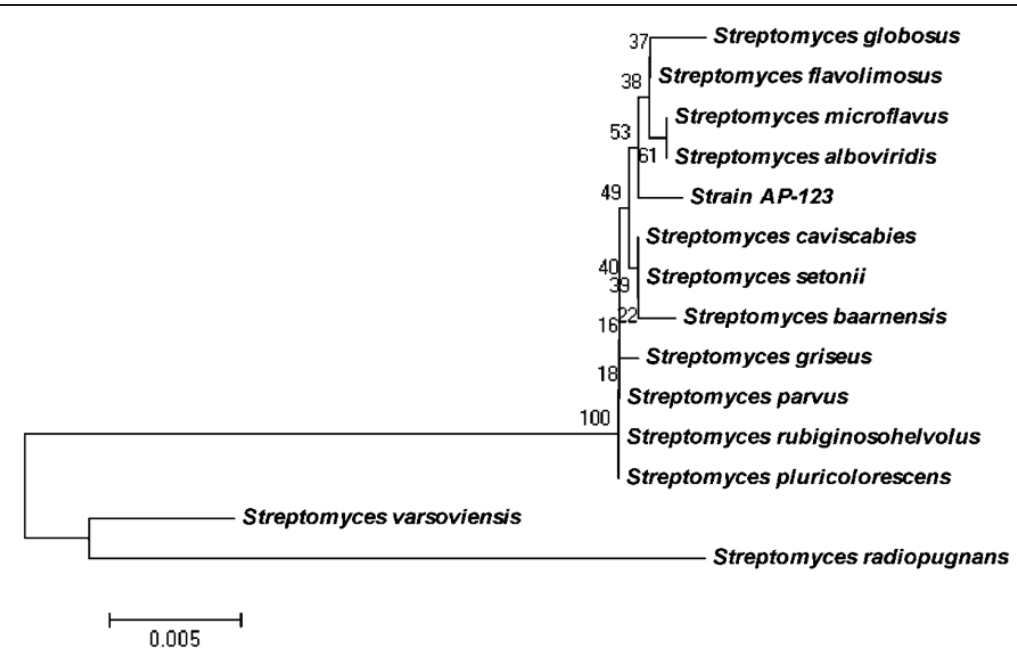

Figure 2 Phylogenetic tree based on 16S rDNA gene sequence showing the relationship between Streptomyces sp. AP-123 and species belonging to the genus Streptomyces was constructed using the neighbour-joining method. Bootstrapping values $>50$ are not mentioned [10].

and then wiped with cotton to remove the moisture content, after that leaf discs of $4 \mathrm{~cm}$ diameter were punched using cork borer. Four different concentrations of the isolated metabolite such as 125, 250, 500 and $1000 \mathrm{ppm}$ were evaluated in this study. The leaves disc were dipped into the metabolite for $15 \mathrm{~min}$. Acetone (Thermo Fisher Scientific India Pvt. Ltd, Mumbai, India) was used as negative control since acetone was used to dissolve the compound and leaf discs dipped in azadirachtin (40.86\% purity, obtained from EID-Parry India Ltd., Chennai) was used as positive control. In each plastic petridish $(1.5 \times 9 \mathrm{~cm})$ wet filter paper was placed to avoid early drying of the leaf discs. Third instar larva of the respective insects was introduced into each petriplates. Progressive consumption of treated and control leaves by the larvae after $24 \mathrm{~h}$ was assessed using Leaf Area Meter (Delta-T Devices, Serial No. 15736 F 96, UK). Leaf area eaten by larvae in treatment was corrected from the negative control. Each concentrations were maintained as five replicates with 10 larvae per replicate (total, $\mathrm{N}=50$ ). The experiment was performed at laboratory conditions $\left(27 \pm 2^{\circ} \mathrm{C}\right)$ with $14: 10$ photoperiod and $75 \pm 5 \%$ relative humidity. Antifeedant activity was calculated according to the formula of Bentley et al. [22].

\section{Larvicidal activity of the polyketide metabolite}

Larvicidal activity was studied using leaf disc no-choice method Basker et al. [20]. Briefly, fresh cotton and castor leaf were obtained from the garden was used in this study. After cleaning the leaves with water leave discs were made and dipped in different concentrations of the compound and assayed as mentioned in antifeedant experiment. After $24 \mathrm{~h}$ the larvae were continuously maintained on the untreated fresh cotton and castor leaves for $H$. armigera and S. litura, respectively. Insect diet was changed every $24 \mathrm{~h}$.
Larval mortality was observed and recorded after $96 \mathrm{~h}$ of treatment. Five replicates were maintained for each treatment with 10 larvae per replicate (total $N=50$ ). The laboratory conditions were maintained as same as in the antifeedant experiment. Percent mortality was calculated according to Abbott [23].

\section{Pupicidal activity of the polyketide metabolite}

The larvae which survived were continuously fed with normal diet as specified in larvicidal activity until they became pupae and adults. Pupicidal activity was calculated by subtracting the number of emerging adults from the total number of pupae.

\section{Larval and pupal durations}

The survived larvae in the treatments were reared on fresh untreated leaves and their larval duration after the treatment was recorded. Pupal period was calculated from the day of pupation to the day of adult emergence.

\section{Statistical analysis}

The data related to antifeedant, larvicidal and pupicidal activities and larval-pupal durations were analysed by one way Analysis of Variance. Significant differences between treatments were determined using Tukey's multiple range tests $(\mathrm{P} \leq 0.05)$. Probit analysis was done to calculate median lethal concentration $\left(\mathrm{LC}_{50}\right)$ and $\mathrm{LC}_{90}$ using SPSS 11.5 version software package [24].

\section{Competing interests}

The authors declare that they have no competing interest.

\section{Authors' contributions}

Conceived and designed the experiments: MVA NAA-D VD. Performed the experiments: MVA VS VD CM. Analyzed the data: MVA NAA-D VD CM. Wrote the manuscript: MVA NAA-D VD SJK. All authors read and approved the final manuscript. 


\section{Acknowledgments}

The authors are grateful to global Research Centre for Biotechnology, Taramani, Chennai, India, Entomology Research Institute, Loyola College and CNU for carrying out this work. Authors are thankful to Addiriyah Chair for Environmental Studies, Department of Botany and Microbiology, College of Science, King Saud University, Riyadh-11451, Saudi Arabia for financial assistance.

\section{Author details}

'Department of Bio-Environmental Chemistry, Chungnam National University, 99 Daehak-Ro, Yuseong-Gu, Daejeon 305-764, Republic of Korea. ${ }^{2}$ Global Research Centre for Biotechnology, Taramani, Chennai, India. ${ }^{3}$ Department of Botany and Microbiology, Addiriyah Chair for Environmental Studies, College of Science, King Saud University, P. O. Box 2455, Riyadh, 11451, Saudi Arabia.

Received: 21 November 2012 Accepted: 30 April 2013

Published: 13 May 2013

\section{References}

1. Zhou CN: A progress and development foresight of pesticidal microorganisms in China. Pesticides 2001, 40:8-10.

2. Rao GVR, Wightman JA, Rao DVR: World review of the natural enemies and diseases of Spodoptera litura (F.) (Lepidoptera: Noctuidae). Insect Sci App/ 1993, 14:273-284

3. Armes NJ, Wightman JA, Jadhav DR, Rao GVR: Status of insecticide resistance in Spodoptera litura in Andhra Pradesh, India. Pest Sci 1997, 50:240-248

4. Jiang L, Ma CS: Progress of researches on biopesticides. Pesticides 2000, 16:73-77.

5. Leonard GC, Julius JM: Review biopesticides: a review of their action, applications and efficacy. Pest Manag Sci 2000, 56:651-676.

6. Tang W, Wei $X, X u H$, Zeng D, Long L: 13-Deoxyitol A, a new insecticidal isoryanodane diterpene from the seeds of Itoa orientalis. Fitoterapia 2009, 80:286-289.

7. Zhang DF: Recent developments in research and utilization of microorganisms. J Agri Sci 1996, 24:44-46.

8. Brenan VS, Greenstein M, Maiese WM: Marine microorganisms as a source of new natural products. Adv Appl Microbioli 1997, 43:57-90.

9. Guan HS, Geng MY, Wang CY: Marine drugs in China towards 21st century. Chinese Marine Drugs 2000, 76:44-47.

10. Valan AM, Duraipamdiyan $\mathrm{V}$, Ignacimuthu S: Antibacterial and antifungal activities of polyketide metabolite from marine Streptomyces sp. AP-123 and its cytotoxic effect. Chemosphere 2013, 90(2):479-487.

11. Kannan P: Biological activity of some medicinal plants and microbes and genetic diversity of Chromobacterium violaceum. Ph.D., Thesis. Chennai, India: University of Madras; 2008.

12. Xiang-Jing W, Ji Z, Chong-Xi L, Dian-Liang G, Hui Z, Ji-Dong W, Yi-Jun Y, Wen-Sheng $X$ : A novel macrocyclic lactone with insecticidal bioactivity from Streptomyces microflavus neau3. Bioorg Med Chem Lett 2011, 21:5145-5148.

13. Becher PG, Keller S, Jung G, Sussmuth RD, Juttner F: Insecticidal activity of 12-epi-hapalindole J isonitrile. Phytochemistry 2007, 68:2493-2497.

14. da Silva SMB, Silva-Werneck JO, Falcao R, Gomes AC, Fragoso RR, Quezado MT, Neto OBO, Aguiar JB, de Sa MFG, Bravo A, Monnerat RG: Characterization of novel Brazilian Bacillus thuringiensis strains active against Spodoptera frugiperda and other insect pests. J Appl Entomol 2004, 128:102-107.

15. Baerson SC, Rimando AM: Polyketides. In Biosynthesis, biological activities, and genetic engineering. Edited by Rimando AM, Baerson SR. Washington DC: American Chemical Society; 2007:2.

16. Harvey BM, Mironenko T, Sun Y, Hong H, Deng Z, Leadlay PF, Weissman KJ, Haydock SF: Insights into polyether biosynthesis from analysis of the nigericin biosynthetic gene cluster in Streptomyces sp. DSM4137. Chem Biol 2007, 14:703-714.

17. Kirst HA: The spinosyn family of insecticides: realizing the potential of natural products research. J Antibiot 2010, 63:101-111.

18. Omura S: Ivermectin: 25 years and still going strong. Int J Antimicrob Agents 2008, 31:91-98.

19. Weissman KJ, Leadlay PF: Combinatorial biosynthesis of reduced polyketides. Nat Rev Microbiol 2005, 3:925-936.
20. Baskar K, Maheswaran R, Kingsley S, Ignacimuthu S: Bioefficacy of Couroupita guianensis (Aubl) against Helicoverpa armigera (Hub.) (Lepidoptera: Noctuidae) larvae. Span J Agric Res 2010, 8(1):135-141.

21. Koul O, Singh G, Singh R, Multani JS: Bio-efficacy and mode-of-action of aglaroxin A from Aglaia elaeagnoidea (syn. A. roxburghiana) against Helicoverpa armigera and Spodoptera litura. Entomol Exp Appl 2004, 114:197-204.

22. Bentley MD, Leonard DE, Stoddard WF, Zalkow LH: Pyrrolizidine alkaloids as larval feeding deterrents for spruce budworm, Choristoneura fumiferana (Lepidoptera: Tortricidae). Ann Entomol Soc Am 1984, 77:393-397.

23. Abbott WS: A method of computing the effectiveness of an insecticide. J Econ Entomol 1925, 18:265-266.

24. Finney DJ: Probit analysis. 3rd edition. London, UK: Cambridge University Press; 1971:383.

doi:10.1186/1471-2180-13-105

Cite this article as: Arasu et al:: Antifeedant, larvicidal and growth inhibitory bioactivities of novel polyketide metabolite isolated from Streptomyces sp. AP-123 against Helicoverpa armigera and Spodoptera litura. BMC Microbiology 2013 13:105.

\section{Submit your next manuscript to BioMed Central and take full advantage of:}

- Convenient online submission

- Thorough peer review

- No space constraints or color figure charges

- Immediate publication on acceptance

- Inclusion in PubMed, CAS, Scopus and Google Scholar

- Research which is freely available for redistribution 